OPEN ACCESS

Edited by:

Miguel Peláez-Fernández,

Tecnatom, Spain

Reviewed by:

Robert Beattie

Institute of Science and Technology

Austria (IST Austria), Austria

Dario Tejera,

University of California, San Francisco,

United States

Jorge F. Mejias,

University of Amsterdam, Netherlands

*Correspondence:

Francisco Javier Roman-Roig

franciscoromanroig@gmail.com

Specialty section:

This article was submitted to

STEM Education,

a section of the journal

Frontiers in Education

Received: 06 February 2020 Accepted: 27 April 2020

Published: 20 May 2020

Citation:

Saucedo-Bendek O, Ewel S and Roman-Roig FJ (2020) Entrepreneurs'

Perception Toward International

Cooperation and Government

Programs Concerning

Entrepreneurship. Front. Educ. 5:57.

doi: 10.3389/feduc.2020.00057

\section{Entrepreneurs' Perception Toward International Cooperation and Government Programs Concerning Entrepreneurship}

\author{
Omaira Saucedo-Bendek ${ }^{1,2,3}$, Sebastián Ewel ${ }^{1,2,4,5,6}$ and Francisco Javier Roman-Roig 1,2,3* \\ ${ }^{1}$ Clubes de Ciencia Bolivia Foundation, Santa Cruz de la Sierra, Bolivia, ${ }^{2}$ Association of Young Entrepreneurs "Juventud \\ Empresa”, Santa Cruz de la Sierra, Bolivia, ${ }^{3}$ tuGerente.com, Santa Cruz de la Sierra, Bolivia, ${ }^{4}$ Aluz Clean Energy, Lima, Peru, \\ ${ }^{5}$ Empresa Eléctrica Agua Azul, Lima, Peru, ${ }^{6}$ Panamerican Securities, La Paz, Bolivia
}

Globally, and regionally, countries are implementing programs and policies to foster entrepreneurship. The most successful programs have aligned efforts by various stakeholders to thrive. This document contrasts the needs of early-stage and aspiring entrepreneurs in Bolivia and their perceptions on the current programs they have attended. The authors use Elma Van de Mortel's model to describe the stages the entrepreneurship undergoes, interpreting Bolivia is in the first of the three stages. Start-Up Chile is used as a benchmark program toward a more sophisticated entrepreneurship structure, to conclude efforts should be made to align stakeholders including the government, financial services, incubators, accelerators, universities, and others.

Keywords: Bolivia, startups, startups ecosystem, aspiring entrepreneurs, early-stage entrepreneurs, incubators, accelerators, government programs and policies

\section{INTRODUCTION}

Entrepreneurship fulfills a major role in the development of the social and economic challenges of many countries. In Latin America, this role is further threatened by the lack of or limited creation and implementation of public policies and programs in entrepreneurship.

Worldwide, government interest in entrepreneurship programs, particularly startup programs, is increasing, with the emergence of government-funded organizations focused on startups and small and medium enterprises' (SMEs) development of their innovative, technological, and funding capabilities (e.g., Start-Up Chile, K-Startup Grand Challenge in South Korea, Enterprise Singapore).

This manuscript serves as an introductory document to understand the general effectiveness of the current government programs targeted for early-stage entrepreneurs and aspiring entrepreneurs in Bolivia, in order to suggest a course of action for its improvement. In this document, "early-stage entrepreneurs" refers to one or more individuals who have majority ownership over a startup or small or medium enterprise of under 5 years of existence, the period called the "valley of death" of business development (European Commision, 2015). "Aspiring entrepreneur" refers to individuals who have not yet launched a startup or SME but desire to do so.

To determine what public entrepreneurship programs could focus on in Bolivia, we surveyed, via online, 106 early-stage entrepreneurs and aspiring entrepreneurs from seven of the nine departments of Bolivia, aged 16 to 25, regarding their experience in the participation of such programs. We asked what type of organization sponsored the programs in which they had 
participated and in which fields these programs were focused. Following, we asked how satisfied the surveyed population was with the program. Finally, we asked what fields they consider are most needed for them to develop their early-stage ventures and/or to launch their ideas. Cumming and Johan (2013) refer to early-stage firms as any firm encompassed between the pre-seed and startup stages of entrepreneurial firm development.

The surveyed population are former participants in nationwide events and entrepreneurship-based workshops, both government and privately sponsored. Participants' information was extracted from organizers' lists of attendees, who received the questionnaire.

Considering the findings, which are described below, we suggest as an example, Start-Up Chile, which could serve as a path Bolivia could follow to develop its entrepreneurial ecosystem. Finally, we highlight the recent developments by other stakeholders, such as universities, financial institutions, and accelerating programs that complement entrepreneurs and public policy.

\section{PERCEPTIONS TOWARD OPPORTUNITIES, CAPABILITIES, AND FEAR OF FAILURE}

There has been an overall negative perception from specialistsincluding academicians, entrepreneurs, accelerator operators, and business people-regarding Bolivian government's support concerning the prioritization of policies in entrepreneurship, with a slight improvement in perception over the period 20082014 in Bolivia (Querejazu, Zavaleta and Mendizabal, 2014).

The conducted survey compares the perception of aspiring and early-stage entrepreneurs toward the area in which they consider they need more support vis-à-vis their perception of the support received from international cooperation and programs focused on entrepreneurship.

In descendant order of occurrences:

\begin{tabular}{ll}
\hline Part A. & Part B. \\
Entrepreneurial Education & Entrepreneurial Education \\
Financing Alternatives & None \\
Participation in Fairs and Events & Participation in Fairs and Events \\
Networking with Suppliers & Financing Alternatives \\
Access to Market (Clients) & Networking with Suppliers \\
New Educational Methods & Access to Market (Clients) \\
Networking & Networking
\end{tabular}

Although there is a general positiveness in entrepreneurs in Bolivia toward self-perception of capabilities, there is a prevalent fear of failure-the highest in the region (Querejazu, Zavaleta and Mendizabal, 2014). This discrepancy between perceived capabilities and opportunities is evidenced by the overall lack of support perceived by aspiring and early-stage entrepreneurs from assistance received from international cooperation and government programs (see Figure 1, Part B).

A predominant and comparatively high fear of failure in entrepreneurship in Bolivia should be considered a worrying issue to be tackled in the creation and implementation of government programs, grants and support to SMEs, startups, and entrepreneurship-related organizations, as well as public policy to foster entrepreneurship. Nonetheless, entrepreneurial spirit and fear of failure are still cultural issues that remain largely uncoded and need to be addressed in subsequent studies with improved measurements (Global Startup Ecosystem Report, 2018).

\section{ENTREPRENEURIAL EDUCATION, FINANCING ALTERNATIVES, AND PARTICIPATION IN FAIRS AND EVENTS}

The role of public initiatives may prove to be the catalyst in fostering entrepreneurship, particularly in the areas of Entrepreneurial Education, Financing Alternatives and Participation in Fairs and Events (see Figure 1, Part A). Government support through programs, policies, and funding fulfill a key role in the development of a sustainable startup ecosystem, and it should be able to adapt to its ecosystem growth (Basso et al., 2018).

Our survey results and this document highlight the importance of the three aforementioned areas for aspiring and early-stage entrepreneurs; the need and evidence for government policy-making, the creation of programs in entrepreneurship, and providing access to financing alternatives.

Entrepreneurial education in early stages plays an important role not only for the knowledge delivered but also for all the skills that it develops in parallel, such as creative thinking, teamwork, and understanding risk (Ganderson, 2019). Entrepreneurial education, including entrepreneurial programs and activities, has produced a significant rise in the percentage of highschool graduates that become entrepreneurs and university graduates, who start their companies sooner than their peers without participation in entrepreneurial education (European Commision, 2015). Concordantly, it is stressed the importance for governments to include entrepreneurial education in the school and university curricula, as well as entrepreneurial training including participation in, at least, "one entrepreneurial experience" during that time (European Commision, 2015). This is consistent with our respondents' perception on entrepreneurial education as the area most needed for their development as entrepreneurs (see Figure 1, Part A).

It is, however, worrying that even though entrepreneurial education is ranked as the most beneficial area from government and international cooperation programs, in the survey sample, only $28 \%$ of respondents perceive a positive impact on this subject (see Figure 1, Part B). This difference may be due to insufficient or poorly-designed programs, or the lack of a formal entrepreneurial education strategy in place (Ganderson, 2019).

The Organisation for Economic Co-operation and Development's (OECD) divides financial techniques and vehicles under four categories. The first category, traditional debt, includes bank loans, credit cards, credit lines, overdrafts, leasing, and factoring. These instruments are typically assetbacked and offer a low risk and low return for the financial 
A Areas perceived as most needed by aspiring and early-stage entrepreneurs.

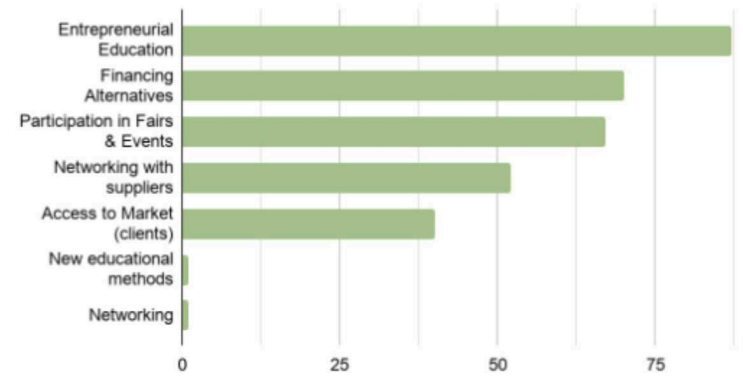

B Areas in which aspiring and early-stage entrepreneurs perceive they have been benefited from assistance from international cooperation and government programs.

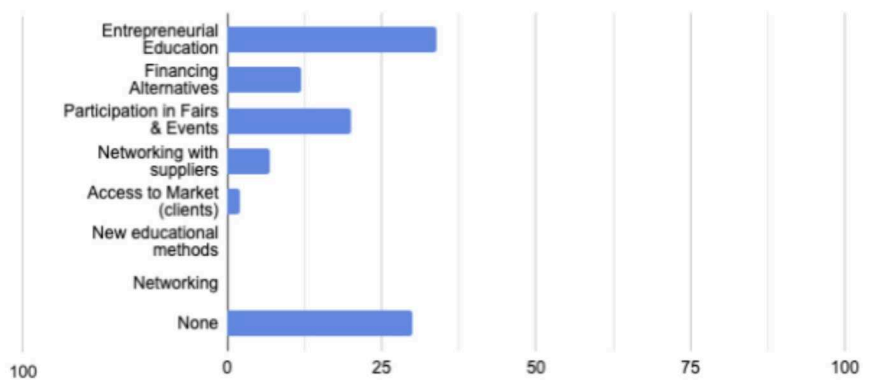

FIGURE 1 | Perception toward the needs from aspiring and early-stage entrepreneurs aged 16-22 in Bolivia vs. perception toward assistance received from international cooperation and government programs (Moed, 2018). Part A: Areas perceived as most needed by aspiring and early-stage entrepreneurs. Part B: Areas in which aspiring and early-stage entrepreneurs perceive they have been benefited from assistance from international cooperation and government programs.

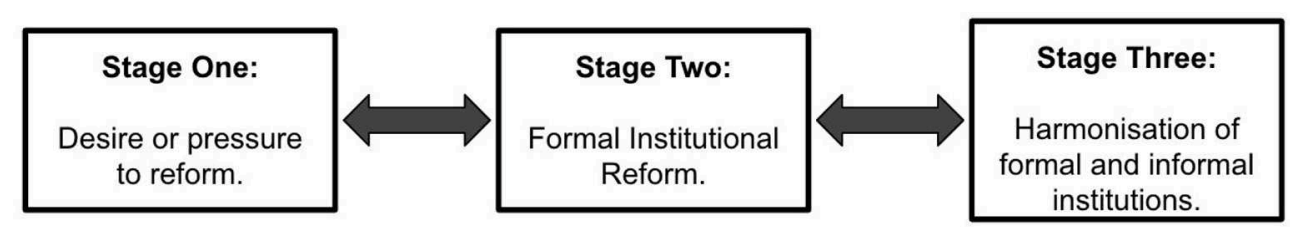

FIGURE 2 | Van de Mortel model of three transition stages.

institution. The second category, alternative debt, includes, mainly, securitized debt, corporate and covered bonds, and crowdfunding (debt). Yield and risk remain relatively low. The third category, "hybrid" instruments, covers subordinated and participating loans, convertible debt, profit participation rights, bonds with warrants and mezzanine instruments. Risk is higher, as well as its expected financial return. The fourth category, equity instruments, includes crowdfunding (equity) private equity, venture capital, and business angel funding. These instruments are used for high-risk investments and take an equity stake in the firm in which they invest (Organisation for Economic Co-operation and Organisation for Economic Co-operation Development, 2013).

In the spectrum of financial instruments and vehicles, traditional finance differs from alternative, hybrid and equity funding, in its financial services provider. Traditional lending is mainly catered by commercial banks, while investors in the equity market provide the funds and assume the risk on the other side of the spectrum. Financing alternatives are perceived as one of the most needed areas for early-stage entrepreneurs (Figure 1, Part A) and this finding is consistent with the European Commission's Public Consultation (European Commision, 2015) that presents $66 \%$ of its respondents' rating "reinforcement of loan guarantees and venture capital facilities" as very important.

The lack of tangible assets by many aspiring and earlystage entrepreneurs poses a significant challenge in traditionaldebt funding, particularly through many traditional financial institutions that are not willing to take the risk on loans without tangible assets as collateral (Bachher and Guild, 1996). This is further reinforced by the OECD's 2015 report in which it is stated that traditional debt funding is "ill-suited for newer, innovative and fast-growing companies," which may pose a higher risk, and that start-ups usually rely on intangibles that are highly firm and industry-specific, and whose use is very limited as collateral in traditional debt operations.

Alternative finance, conversely, including peer-to-peer lending, and crowdfunding have presented significant growth in other regions, and efficacy on loan allocation to SMEs and startups (Basso et al., 2018). Furthermore, raising a funding round and including outside investors in the early-stages (from ideation to seed-stage) may prove pivotal to the development, growth acceleration and further funding (Global Startup Ecosystem Report, 2018).

Broadening the range of financial alternatives is a first step to take for financial institutions and governments in offering access to startup funding (Organisation for Economic Co-operation Development, 2015). In order to suit new financial instruments and vehicles for startups, it is critical that governments, financial institutions, accredited startup investors, and startups increase their awareness and understanding of such instruments.

Between 2017 and 2018, Australia and the United States created a regulatory sandbox to test new financial products, enabling the creation of new viable financial alternatives to traditional finance, and to foster the creation and implementation of solutions created by fintech startups. During the last 
lustrum, Switzerland and Mexico have created flexible regulation for fintech startups and established companies, facilitating crowdfunding models and new fintech business models to be tested and implemented without excessive bureaucracy (Organisation for Economic Co-operation Development, 2019).

Participation in fairs and events is perceived as the third most needed area for aspiring and early-stage entrepreneurs (see Figure 1, Part A), and it may improve their global connectedness and contact to a culture of founders helping founders, insightful and valuable mentoring from investors and local experts, along with improvement of local connectedness with local support for startups and valuable local relationships and partnerships (Global Startup Ecosystem Report, 2019).

Governments, international and local organizations may largely improve Bolivia's current state of development regarding entrepreneurship, supported by indication that countries with higher startup policy adoption rates tend to have higher-performing startup ecosystems (Global Startup Ecosystem Report, 2019). This report uses the European policy scoreboard that contains the following policy pillars: institutional framework, skills and education, access to talent, access to capital, and thought leadership.

In order to ameliorate Bolivia's startup ecosystem development it is of paramount importance that all stakeholders acknowledge their role in the ecosystem. Stakeholders include research institutions, educational institutions, Government institutions, funding organizations and firms, communities, corporations and support organizations (Basso 2018).

Startup incubators and accelerators are organizations that work as connectors between aspiring entrepreneurs (for aspiring entrepreneurs or idea-stage startups) and early-stage entrepreneurs (for accelerators) to mentorship, educational frameworks and support, potential investors, and other mechanisms needed for the incubation (i.e., materialization from idea to startup) and acceleration (i.e., business model validation and growth) processes.

Research centers, institutions of higher education, combined with improvements in intellectual property protection and promotion, are core areas of improvement for Governments, policy-makers, and other key stakeholders (Global Startup Ecosystem Report, 2018).

Two major examples have proven successful as promoters of entrepreneurship in the region: Start-Up Chile and Clubes de Ciencia Bolivia. Start-Up Chile, a government-run program funded by Chile's CORFO (Chilean Government's Corporation of Promotion), started providing equity-free grants, mentoring, space, and networking events for foreign and local entrepreneurs who aim to bootstrap in Chile in 2010 (González-Uribe, 2015). Start-Up Chile has set the standard for public programs in the region, being replicated by several countries' public and private sectors (i.e., Startup Mexico, Startup Peru, Startup Brazil).

The Start-Up Chile model has been used as the basis for the creation of similar programs in many other countries. Moreover, it is argued that Government's support via policy-making, public programs and organizations is paramount for the consolidation of a startup ecosystem where successful entrepreneurs emerge constantly (González-Uribe, 2015). Results provided by Start-Up Chile demonstrate the positive impact they had regarding the capital raised, sales generated, survival rate and increase in client portfolio for the startups (El Mercurio, 2020).

The Bolivian Government, as any Government in a similar phase of entrepreneurial development, may need to design a program that covers the most important needs of early entrepreneurs, otherwise an incomplete framework may prove to be an inefficient deployment of resources. This program may constitute a loop that enables the entrepreneurial ecosystem to grow, providing entrepreneurial education, access to funding alternatives, and an automatic process of selection for mature projects and startups (González-Uribe, 2015).

Clubes de Ciencia Bolivia (CdeCBo) is one of Bolivia's most renowned organizations in science, technology, and entrepreneurship education (Bolivian Chamber of Senators Press Release, 2015; Los Tiempos, 2020). CdeCBo reaches to students from diverse backgrounds and from every department of the country, with more than 500 students participating in its main activities. CdeCBo has generated high impact on the development, promotion, advising and policy-making of key projects in Bolivia, including the plans for the country's first innovation district, free-of-cost hackathons and workshops with Spanish-speaking instructors from MIT, Harvard, UCSF, Google, Dropbox, Twilio, and local entrepreneurs, scientists, and researchers as co-instructors (Carosso et al., 2019; Ferreira et al., 2019). CdeCBo has also led the creation of the Entrepreneurship Act, and its former President is the newlyappointed and first Science, Technology and Innovation Ambassador of Bolivia (becoming the first Ambassador of its kind in a Latin American country). CdeCBo is a key player in pressuring reform in Bolivia, as will be inferred from the description below.

\section{PAVING THE WAY FOR TRANSFORMATION}

Following Van de Mortel's Model of Three Transition Stages (Van de Mortel, 2002) as a framework to enhance the playing field for entrepreneurs, the results suggest the surveyed sample finds itself in the first stage of the framework, "desire or pressure to reform" (see Figure 2 for an illustration of the stages). The desire or pressure to reform, the first of the stages, comes from the country's freedom to reform. The survey suggests this could be the case, furthermore impulsed by the need to transform Bolivia's economic dynamics, evidenced by the low innovation ranking in the World Economic Forum's Competitiveness Report 2019. Stakeholders, including the government, universities, public and private institutions, and others should perceive this as an opportunity to foster programs that promote entrepreneurship starting with those fields entrepreneurs and aspiring entrepreneurs are in need of, identifying these fields through further research. Stakeholders can act as key catalyzers of the entrepreneurial ecosystem, setting the guidelines and kickstarting the decision-making process to begin the development and implementation of new policies. 
Furthermore, the research by Van de Mortel highlights the need for transition countries to rely on past experiences.

Considering the prior paragraph, we feature initiatives, such as Start-Up Chile as benchmarks for Bolivia, regarding the second stage initiative in Van de Mortel's Model. The second stage is focused on "formal institution reform," which comes as a response to the prior stage. The Start-Up Chile case exemplifies this second stage, bringing together institutional stakeholders, lead by government-backed CORFO and three ministries, and aligns the objectives of financiers, corporations, incubators and accelerators, universities, and other private and public institutions in order to foster entrepreneurial development through public policies focused on encouraging entrepreneurs and other relevant stakeholders in the ecosystem.

Start-Up Chile has shown outstanding results. From 2010 to 2018 it had a portfolio worth over USD 1.4 billion, global revenues of USD 700 million, exited over 40 investments and had raised over USD 1 billion, raising almost $40 \%$ of that figure in 2018 alone (Moed, 2018). Results where not only positive for the program, but Chile is the third main destination for Venture Capital (i.e., private equity financing mainly aimed at startup funding, shortened as VC) investments in Latin America, only behind giants Brazil and Mexico, receiving over 10\% of all VC investment in the region (Azevedo, 2019).

The figures priorly presented already hint Chile has entered the third stage in Van de Mortel's model, which is the "Harmonization of Formal and Informal Institutions." This third and final stage is characterized by the "change of economic behavior of agents." Considering the previous, the Start-Up Chile case serves as an example of a roadmap to foster the entrepreneurial ecosystem and a transition between the three stages of Van de Mortel's model.

\section{RECENT DEVELOPMENTS ON ENTREPRENEURIAL EDUCATION AND FINANCING ALTERNATIVES}

Universities, accelerators, and financial institutions fulfill an important role and influence over early-stage and aspiring entrepreneurs' perceptions of international cooperation and government programs' purpose. However, universities are not fulfilling their role as key stakeholders because of their significant economic repercussions in the region (Hayter, 2016).

Unfair competition from education regulators with private universities coupled with a conservative educational model has created a steady flow of the talent pool to big companies focused on employability rather than the creation and fostering of innovation and entrepreneurship (Roman-Roig, 2018).

In Bolivia, there is a recent rise of interest in creating educational institutions, particularly startup accelerators, yet there has been slow progress in the process of startups' incubation. A considerable gap has been created between very early-stages of entrepreneurship and the acceleration of startups that are already generating significant revenue. Universities' involvement in the entrepreneurial ecosystem is a key component in the generation of innovation and the specialization of the talent pool, with essential inputs, such as the creation of incubators (Mian, 2011).

Regarding new financing alternatives, Banco de Desarrollo Productivo's (BDP) "Capital Semilla" program funded by the Swiss Cooperation is having countrywide reach and impact in traditional small and medium enterprises and experimental programs with startups. As a development bank, BDP manages several trusts with sufficient funds focused on kickstarting and supporting very early-stage entrepreneurs and growth-stage startups. The allocation of funds has followed mainly a debt structure with a low or zero interest rate, with increasing rates for follow-up programs in development. In spite of these recent developments, commercial banks and other financial institutions (e.g., foundations and other NGOs in charge of managing trusts) continue to be major sources of financing, being only surpassed by entrepreneurs' personal savings (Querejazu, Zavaleta and Mendizabal, 2014).

\section{CONCLUSIONS}

The survey findings show a ripe entrepreneurial ecosystem, entering the first stage of Van de Mortel's Model of Three Transition Stages, led by stakeholders, such as CdeCBo. Employing a model similar to Chile's Start-Up Chile, where agents have changed their economic behavior, could potentially transform Bolivia's economy.

On the positive side, the desire and pressure to reform are latent, however other stakeholders must be aligned with these goals to foster entrepreneurship, which, according to Van de Mortel, will occur during the second stage.

There is a clear and general dissatisfaction in the perceived benefit in assistance from government and international cooperation programs concerning entrepreneurship. This should represent a challenge and an opportunity for policymakers, government officials and international cooperation managers in the creation, promotion and implementation of entrepreneurship-focused policies in education, innovation, and business creation, access to financing (particularly alternative financing), support in the development of fintech ventures and flexible regulation, and configuration and participation of entrepreneurship-related fairs and events.

Finally, we conclude that further research should be conducted in order to analyze the effectiveness of educational and government programs concerning entrepreneurship and to discern which type of educational and government programs have proven to be more useful for entrepreneurs and aspiring entrepreneurs in audiences with similar profiles as the one we surveyed. With the findings, entering the second stage of the framework will suggest effective public policy. Finally, research regarding behavioral economics should be conducted to bring together formal and informal institutions effectively, in order to understand how psychological aspects, specific to the Bolivian entrepreneurs impact the economics behind the policy implementation. 


\section{ETHICS STATEMENT}

The Clubes de Ciencia Bolivia Foundation Review Committee reviewed and approved the design and execution of this study. The survey contained in this study was done by the authors, it was done as part of the Clubes de Ciencia Bolivia annual program, and as a subsequent study of Effective participatory science education in a diverse Latin American population by Ferreira et al. In accordance with Bolivian regulations, students were informed about the study prior to the application process.

\section{REFERENCES}

Azevedo, M. A. (2019). Latin America Has 'Arrived' Among Global VCs. Retrieved on January 30, 2020 from: https://news.crunchbase.com/news/latin-americahas-arrived-among-global-vcs/

Bachher, J., and Guild, P. (1996). Financing early stage technology based companies: investment criteria used by investors. Front. Entrepren. Res. Available online at: https://www.researchgate.net/publication/256420976_ Financing_early_stage_technology_based_companies_investment_criteria_ used_by_investors_Frontiers_of_Entrepreneurship_Research

Basso, A., Baltar, E., and Andonova, E. (2018). Startup Innovation Ecosystems in Southern Europe. Brussels: European Commission, JRC113872, 4-9.

Bolivian Chamber of Senators Press Release (2015). Senado otorga máximas condecoraciones a personalidades e instituciones destacadas. Available online at: https://web.senado.gob.bo/prensa/noticias/senado-otorga-m \%C3\%A1ximas-condecoraciones-personalidades-e-instituciones-destacadas

Carosso, G. A., Ferreira, L. M. R., and Mostajo-Radji, M. A. (2019). Scientists as non-state actors of public diplomacy. Nat. Hum. Behav. 3, 1129-1130. doi: 10.1038/s41562-019-0716-1

Cumming, D. J., and Johan, S. A. (2013). Venture Capital and Private Equity Contracting: An International Perspective, Amsterdam: Elsevier, 7, 511.

El Mercurio (2020). 10 Años de Start-Up Chile: cifras revelan un alto retorno de la inversión, pero bajo financiamiento para negocios liderados por mujeres. Santiago: El Mercurio Newspaper.

European Commision (2015). Public Consultation on the Entrepreneurship 2020 Action Plan, Brussels: Directorate General Enterprise and Industry, EC, 12-20.

Ferreira, L. M. R., Carosso, G. A., Montellano Duran, N., Bohorquez-Massud, S. V., Vaca-Diez, G., Rivera-Betancourt, L. I., et al. (2019). Effective participatory science education in a diverse Latin American population. Palgrave Commun. 5:63. doi: 10.1057/s41599-019-0275-0

Ganderson, J. (2019). The Entrepreneurialism 2020 Action Plan: Practical Steps for Renewal, 89 Initiative, London, UK: The 89 Initiative - 1989 Generation Initiative, LLC, 22.

Global Startup Ecosystem Report (2018). Succeeding in the New Era of Technology, Startup Genome, Startup Genome \& Global Entrepreneurship Network, 21, 34.

Global Startup Ecosystem Report (2019). Startup Genome, Startup Genome \& Global Entrepreneurship Network, 24, 40. Available online at: https:// startupgenome.com/

González-Uribe, J. (2015). The Case of Start-up Chile. A Pioneering Program to Attract Talent and Promote Entrepreneurship. Public Policies and Productive Transformation Series $\mathrm{N}^{\circ} 18 / 2015$. CAF Development Bank of Latin America, $11,16,17,31,32$.

Hayter, C. S. (2016). A trajectory of early-stage spinoff success: the role of knowledge intermediaries within an entrepreneurial university ecosystem. Small Bus. Econ. 47, 633-656. doi: 10.1007/s11187-0169756-3

\section{AUTHOR CONTRIBUTIONS}

OS-B, SE, and FR-R wrote this manuscript.

\section{ACKNOWLEDGMENTS}

We would like to thank Clubes de Ciencia Foundation and Mohammed A. Mostajo-Radji for their feedback and support in this initial manuscript.

Los Tiempos (2020). Presidenta Añez compromete apoyo al conocimiento, la innovación y el emprendimiento. Available online at: https://www.lostiempos. com/tendencias/tecnologia/20200109/presidenta-anez-compromete-apoyoal-conocimiento-innovacion

Mian, S. (2011). University's involvement in technology business incubation: what theory and practice tell us? Int. J. Entrepren. Innov. Manag. 13, 113-121. doi: 10.1504/IJEIM.2011.038854

Moed, J. (2018). Start-Up Chile's Impact 2010-2018: Inside The Revolutionary Startup Accelerator. Retrieved on January 30, 2020 from: https://www.forbes. com/sites/jonathanmoed/2018/11/19/start-up-chiles-impact-2010-2018inside-the-revolutionary-startup-accelerator/\#34fe3baa6dc5

Organisation for Economic Co-operation and Development (2013). Alternative Financing Instruments for SMES and Entrepreneurs: The Case of Mezzanine Finance. Paris: OECD, 7.

Organisation for Economic Co-operation and Development (2015). New Approaches to SME and Entrepreneurship Financing: Broadening the Range of Instruments. Synthesis report, OECD, 5-7.

Organisation for Economic Co-operation and Development (2019). Financing SMEs and Entrepreneurs. An OECD Scoreboard. Regulatory Approaches and Targeted Policies Are in Place to Support Fintech Developments. Paris: OECD.

Querejazu, V., Zavaleta, D., and Mendizabal, J. (2014) Global Entrepreneurship Monitor: Bolivian National Report 2014. Escuela de la Producción y la Competitividad de la Universidad Católica Boliviana "San Pablo".

Roman-Roig, M. (2018). Creation of social entrepreneurship hubs in Bolivian universities (Master Thesis), Economics \& Social Sciences \& Solvay Business School, Vrije Universiteit Brussel.

Van de Mortel, E. (2002). An Institutional Approach to Transition Processes. Burlington, VT: Ashgate Pub Limited.

Conflict of Interest: OS-B, and FR-R are employed by the company tuGerente, which has been part of Generation 21 cohort of startups accelerated in Start-Up Chile. G21 Seed Program started in February 2019 and finished in November 2019. Start-Up Chile does not invest nor take equity participation or any participation and/or control in the startups accelerated in all their programs. SE is employed by the company Panamerican Securities. All the authors have participated and are currently affiliated to The Clubes de Ciencia Bolivia Foundation. The authors declare that the research was conducted in the absence of any commercial or financial relationships that could be construed as a potential conflict of interest.

Copyright (c) 2020 Saucedo-Bendek, Ewel and Roman-Roig. This is an open-access article distributed under the terms of the Creative Commons Attribution License (CC $B Y)$. The use, distribution or reproduction in other forums is permitted, provided the original author(s) and the copyright owner(s) are credited and that the original publication in this journal is cited, in accordance with accepted academic practice. No use, distribution or reproduction is permitted which does not comply with these terms. 